\title{
Acute pericarditis following endoscopy
}

\author{
Michael Mohseni, Theodore Szymanski
}

Department of Emergency Medicine, Mayo Clinic, Jacksonville, Florida, USA

\section{Correspondence to}

Dr Michael Mohseni,

mohseni.michael@mayo.edu

Accepted 11 January 2018
Check for updates

To cite: Mohseni $\mathrm{M}$ Szymanski T. BMJ Case Rep Published Online First: [please include Day Month Year]. doi:10.1136/bcr-2017 222825

\section{SUMMARY}

The differential diagnoses for patients presenting with chest discomfort after endoscopy remain broad. In addition to infectious, traumatic and bleeding complications, intrinsic cardiac pathology should be considered. Though rare, pericarditis and pericardial tamponade are additional entities that the clinician should consider when evaluating these patients. We present a 74-year-old man who arrived to the emergency department with substernal chest discomfort that began shortly after upper and lower endoscopy the previous day. Biopsies were obtained during the procedure (ileal and colonic mucosa) without complication. The patient reported worsening chest discomfort with deep inspiration or lying flat. ECG was significant for diffuse ST-segment elevation and PR depression. Cardiac workup was otherwise negative; the patient improved with conservative measures. In this case report, we describe a little known complication after upper endoscopy. By highlighting the clinical features of pericarditis in this setting, the provider can be alert to recognise and promptly treat this clinical entity.

\section{BACKGROUND}

Patients may present to emergency department (ED) with complaints both prior to and after endoscopy. The differential diagnoses for patients presenting with chest discomfort after upper endoscopy remain broad. In addition to infectious, traumatic and bleeding complications, intrinsic cardiac pathology needs to be considered by the treating provider. Though rare, pericarditis and pericardial tamponade are plausible entities that the clinician should entertain when evaluating any patient with non-ischaemic chest discomfort. ${ }^{1}$ We report a case of acute pericarditis after upper endoscopy and outline the clinical features associated with this presentation.

\section{CASE PRESENTATION}

A 74-year-old man presented to the ED with the chief complaint of substernal chest discomfort. The pain began acutely after awaking from endoscopy the day prior and had been constant since that time. The patient underwent upper and lower endoscopy the previous day for 4 weeks of chronic diarrhoea since returning from a trip to Thailand. This procedure was performed using fentanyl and midazolam for sedation without general anaesthesia or intubation. Random biopsies were obtained of the ileal and colonic mucosa during the endoscopies but no other interventions or therapies were performed. He had no chest pain or other thoracic complaints prior to the endoscopy. The patient reported associated shortness of breath and worsening chest discomfort with deep inspiration or lying flat. There was no fever, chills, cough, sore throat or vomiting. Medical history was significant for coronary artery disease and obstructive sleep apnoea. On evaluation by the ED physician, the patient was found to be in no significant distress, with a blood pressure of $168 / 55 \mathrm{~mm} \mathrm{Hg}$, heart rate of 81 beats/min, respiratory rate of 18 breaths/min and temperature of $36.3^{\circ} \mathrm{C}$. Oxygen saturation was $96 \%$ on room air. Physical examination was unremarkable, with normal cardiac auscultation and normal lung sounds. Chest X-ray was obtained; radiology interpretation was small left pleural effusion and retrocardiac atelectasis (figure 1A,B). Additionally, ECG was performed, revealing a sinus rhythm with diffuse ST-segment elevation and PR depression (figure 2). CT of the chest and echocardiography revealed a trace pericardial effusion, but no evidence of mediastinitis or valvular dysfunction. The trace left pleural effusion and atelectasis was also confirmed on the CT imaging. His troponin was undetectable. Arrangements were made for admission to the cardiology service. The patient improved with conservative measures, had an uneventful hospital course and was discharged 2 days later in good, improved condition.

\section{INVESTIGATIONS}

Chest X-ray, CT, echocardiography and ECG were performed (as above).

\section{DIFFERENTIAL DIAGNOSIS}

The differential diagnosis included oesophageal perforation, mediastinitis, pericarditis, pericardial tamponade, cardiac ischaemia and myocardial infarction.

\section{TREATMENT}

High-dose aspirin therapy consisting of $650 \mathrm{mg}$ three times daily for 10 days was used as the primary treatment strategy for this patient's acute pericarditis. Steroids were avoided because of risk of delayed myocardial healing.

\section{OUTCOME AND FOLLOW-UP}

This patient had pericarditis manifesting acutely after endoscopy. Other than the random biopsies and endoscopic procedure itself, no other risk factors were identified as a cause for his pericarditis. There was no other evidence of autoimmune or inflammatory processes. His symptoms improved 


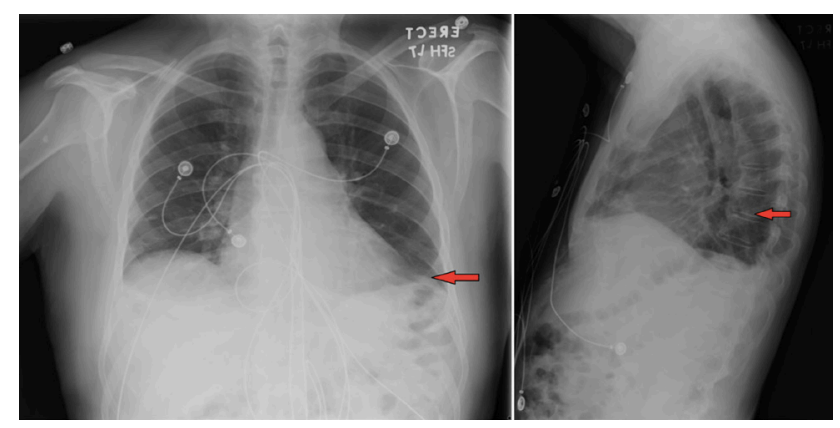

Figure 1 Initial posteroanterior and lateral chest X-ray, showing small left pleural effusion and retrocardiac atelectasis (arrows).

with high-dose aspirin therapy, and he was discharged in good condition after a 2-day hospital course.

\section{DISCUSSION}

Acute pericarditis has been reported in $0.1 \%$ of hospitalised patients and $5 \%$ of ED patients with non-ischaemic chest pain. ${ }^{1}$ Idiopathic and viral causes are cited most often as the aetiology for acute pericarditis in developed countries, though iatrogenic trauma such as pacemaker perforations, cardiopulmonary resuscitation or post-thoracic surgery can also be implicated. ${ }^{2-4}$ Endoscopy, however, has not been routinely identified as a risk factor for the development of pericarditis.

Chest pain is reported in $>95 \%$ of patients with acute pericarditis. ${ }^{5}$ Our patient also had classic symptoms of pleuritic chest discomfort, improved by sitting upright. ECG is useful in most cases of pericarditis: one series reported typical ECG changes and evolution in $60 \%$ of patients. ${ }^{5}$ The initial ECG manifestations of pericarditis, as seen in our patient (figure 2), include diffuse ST elevation (commonly concave up) and reciprocal ST depression in leads aVR and V1. The pattern of atrial injury is reflected in PR-segment elevation in lead aVR and PR-segment depression in the limb leads and chest leads, primarily V5 and V6. ${ }^{2}{ }^{6}$ The evolution of ECG changes varies from patient to patient and with the institution of therapeutic measures.

A review of the literature reveals no previous reported cases of acute pericarditis from upper endoscopy only; however, three series (four patients total) reported pericarditis in those who concomitantly underwent endoscopic variceal sclerotherapy (EVS).$^{8-10}$ In all cases oesophageal varices were being treated, and in two of the patients oesophageal perforation was suspected. In these two patients, pericardial tamponade was also observed as a complication. In the case series by Caletti et al, it was surmised that EVS created an inflammatory reaction in the surrounding tissues, subsequently leading to pericarditis. Caletti

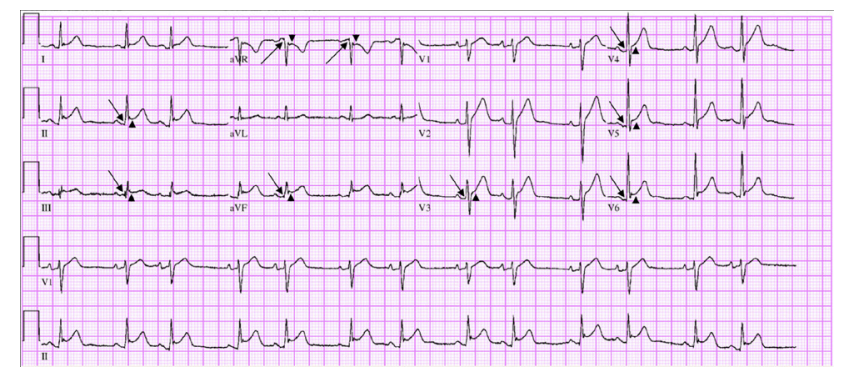

Figure 2 Initial ECG rhythm strips, notable for PR elevation in aVR and diffuse PR depression (arrows) as well as ST depression in aVR and diffuse ST elevation (arrowheads). et al also suggest that perhaps this phenomenon is under-recognised due to the mild nature of the symptoms that patients may experience. ${ }^{9}$ Otherwise, the risks of combined upper and lower endoscopy are similar to each procedure being performed alone, for example, perforation, bleeding, aspiration or adverse sedation events. ${ }^{11}$

Based on our case report, we would suggest that practitioners keep the possibility of acute pericarditis on their differential in the postendoscopy patient. A heightened awareness should accompany those patients who specifically underwent intervention during the endoscopic procedure. Treatment of pericarditis is directed toward the underlying aetiology, with a focus on preventing complications such as cardiac tamponade or constrictive pericarditis. Given the benign course of pericarditis in the majority of patients $(>80 \%)$, patients are often treated presumptively with non-steroidal anti-inflammatory drugs and colchicine. ${ }^{12}$ In our patient, colchicine was avoided because of his ongoing diarrhoeal complaint.

\section{Learning points}

- Consider pericarditis and pericardial tamponade on the differential diagnosis in the patient presenting with chest pain after upper endoscopy.

- The clinician should definitively rule out other life-threatening causes as well, such as oesophageal perforation, mediastinitis and cardiac ischaemia, when evaluating the patient with acute chest pain after endoscopy.

- Treatment of pericarditis is directed at the underlying cause, but the majority of cases have a benign course with appropriate therapy.

Contributors TS: provided details and clinical course for the patient in this case report. MM: reviewed the case and drafted the case report for submission.

\section{Competing interests None declared.}

Patient consent Detail has been removed from this case description/these case descriptions to ensure anonymity. The editors and reviewers have seen the detailed information available and are satisfied that the information backs up the case the authors are making.

Provenance and peer review Not commissioned; externally peer reviewed.

(c) BMJ Publishing Group Ltd (unless otherwise stated in the text of the article) 2018. All rights reserved. No commercial use is permitted unless otherwise expressly granted.

\section{REFERENCES}

1 Spodick DH. Acute cardiac tamponade. N Engl J Med 2003:349:684-90.

2. Troughton RW, Asher CR, Klein AL. Pericarditis. Lancet 2004;363:717-27.

3 Lange RA, Hillis LD. Clinical practice. Acute pericarditis. N Eng/ J Med 2004;351:2195-202.

4 Little WC, Freeman GL. Pericardial disease. Circulation 2006;113:1622-32.

5 Imazio M, Demichelis B, Parrini l, et al. Day-hospital treatment of acute pericarditis: a management program for outpatient therapy. J Am Coll Cardiol 2004;43:1042.

6 Spodick DH. Acute pericarditis: current concepts and practice. JAMA 2003;289:1150.

7 Spodick D. The pericardium: a comprehensive textbook. New York: Marcel Dekker, 1997:46-64.

8 Brown DL, Luchi RJ. Cardiac tamponade and constrictive pericarditis complicating endoscopic sclerotherapy. Arch Intern Med 1987;147:2169-70.

9 Caletti GC, Brocchi E, Labriola E, et al. Pericarditis: a probably overlooked complication of endoscopic variceal sclerotherapy. Endoscopy 1990;22:144-5.

10 Gupta S, Thompson K, Grellier L. Purulent pericarditis: a complication of endoscopic oesophageal variceal sclerotherapy. Endoscopy 2005;37:688.

11 Triadafilopoulos G, Aslan A. Same-day upper and lower inpatient endoscopy: a trend for the future. Am J Gastroenterol 1991;86:952-5.

12 Maisch B, Seferović PM, Ristić AD, et al. Guidelines on the diagnosis and management of pericardial diseases executive summary; The Task force on the diagnosis and management of pericardial diseases of the European society of cardiology. Eur Heart $J$ 2004;25:587. 
Copyright 2018 BMJ Publishing Group. All rights reserved. For permission to reuse any of this content visit http://group.bmj.com/group/rights-licensing/permissions.

BMJ Case Report Fellows may re-use this article for personal use and teaching without any further permission.

Become a Fellow of BMJ Case Reports today and you can:

- Submit as many cases as you like

- Enjoy fast sympathetic peer review and rapid publication of accepted articles

Access all the published articles

- Re-use any of the published material for personal use and teaching without further permission

For information on Institutional Fellowships contact consortiasales@bmjgroup.com

Visit casereports.bmj.com for more articles like this and to become a Fellow 